\title{
The use of antiviral drugs for influenza: Recommended guidelines for practitioners
}

\author{
Upton D Allen MBBS FRCPC ${ }^{1}$, Fred Y Aoki MD FRCPC ${ }^{2}, \mathrm{H}_{\text {Grant Stiver MD FRCPC }}^{3}$, \\ for the Canadian Paediatric Society and the Association of Medical Microbiology and Infectious Disease Canada
}

UD Allen, FY Aoki, HG Stiver, for the Canadian Paediatric Society and the Association of Medical Microbiology and Infectious Disease Canada. The use of antiviral drugs for influenza: Recommended guidelines for practitioners. Can J Infect Dis Med Microbiol 2006;17(5):273-284.

The present document outlines current guidelines and supporting literature relating to the use of antiviral drugs for chemoprophylaxis and influenza illness therapy in paediatric and adult settings. The focus is on the management of influenza in interpandemic periods. Where appropriate, the areas in need of additional research are identified. It will be necessary to update aspects of these guidelines as new information emerges. The recommendations that follow represent the results of a joint effort supported by the Canadian Paediatric Society and the Association of Medical Microbiology and Infectious Disease Canada.

\section{Le recours aux antiviraux contre l'influenza : Les lignes directrices recommandées pour les praticiens}

Le présent article expose les lignes directrices actuelles et les publications justificatives reliées au recours aux antiviraux pour la chimioprophylaxie et le traitement de l'influenza en milieu pédiatrique et chez les adultes. On s'intéresse à la prise en charge de l'influenza entre les pandémies. Les domaines qui nécessitent des recherches plus approfondies sont indiqués. Il faudra mettre à jour les divers aspects des présentes lignes directrices à mesure qu'on obtiendra de nouvelles données. Les recommandations qui suivent représentent les résultats d'un effort conjoint soutenu par la Société canadienne de pédiatrie et l'Association pour la microbiologie médicale et l'infectiologie Canada.

Key Words: Antiviral therapy; Influenza; M2 inhibitors; Neuraminidase inhibitors

\section{INTRODUCTION AND BACKGROUND}

Influenza A viruses, and occasionally influenza B strains, cause recurrent, almost annual epidemics in Canada, with significant morbidity, mortality and economic loss (1). The principle of immunization to minimize the impact of influenza illness in individuals and populations is widely accepted, as is the notion that antiviral drugs have a role in the management and control of influenza. However, our knowledge of best practices in immunization, such as the question of immunizing healthy children, adults and pregnant women, continues to evolve, as do our recommendations on the optimal use of antiviral drugs. While acknowledging that the latter area of practice continues to evolve, it was thought appropriate, nonetheless, to develop contemporary guidelines on the use of antiviral drugs for chemoprophylaxis and therapy, which are appropriate for the management of influenza in interpandemic periods. The recommendations that follow represent the results of a joint effort supported by the Canadian Paediatric Society (CPS) and the Association of Medical Microbiology and Infectious Disease
Canada (AMMI Canada). The guidelines reflect the current state of knowledge regarding the use of influenza antiviral drugs, and may be modified by additional, forthcoming research data. Additional information on strategies to prevent influenza illness in the interpandemic period may be obtained from the annual statement by the National Advisory Committee on Immunization (2).

\section{INFLUENZA ANTIVIRAL DRUGS}

In Canada, currently licensed influenza antiviral agents are composed of two classes of drugs: the influenza A virus M2 ion channel blocker amantadine (Symmetrel, Endo Pharmaceuticals, USA), and the influenza $A$ and $B$ virus neuraminidase inhibitors (NAIs) zanamivir (Relenza, GlaxoSmithKline, USA) and oseltamivir (Tamiflu, Roche Laboratories Inc, USA).

Rimantadine, an M2 ion channel blocker similar to amantadine but with fewer side effects, is licensed in the United States but not in Canada. Although a rationale for marketing rimantadine in Canada has recently been published (3), it is

${ }^{1}$ University of Toronto, Toronto, Ontario; ${ }^{2}$ University of Manitoba, Winnipeg, Manitoba; ${ }^{3}$ University of British Columbia, Vancouver, British Columbia

Correspondence: Drs Upton D Allen, Fred Y Aoki and H Grant Stiver, clo 555 University Avenue, Toronto, Ontario M5G 1 X8.

Telephone 416-813-8129, fax 416-813-8404

Received and accepted for publication June 26, 2006 
not currently approved for use; therefore, influenza chemoprophylaxis and therapy with this drug will not be discussed further. Cross-resistance occurs between amantadine and rimantadine. These agents have no effect on influenza B due to differing conformation of the proton channel protein BM2.

Similarly, ribavirin administered to children ill with influenza as aerosol or oral tablets has been demonstrated to ameliorate symptoms and to be acceptably safe. However, because ribavirin is not licensed for influenza treatment or prophylaxis in Canada, it will also not be discussed further.

The NAIs are effective against recently emerging avian strains of influenza A H5N1 (4-6), but virtually all of these highly virulent strains are resistant to amantadine (7).

\section{Antiviral drugs can be useful in the following settings:}

1. As prophylaxis in a pandemic where an antigenic shift in the influenza A virus has resulted in widespread influenza for which a vaccine is not yet available.

2. As prophylaxis where a major antigenic drift or mutation has resulted in circulation of an influenza strain not well matched to the currently available vaccine (eg, drift from A/Sydney [H3N2]-like virus to A/Fujian [H3N2]).

3. As interim prophylaxis of high-risk patients who have received vaccine during an outbreak but need time to develop a protective antibody response (two to three weeks postvaccination).

4. As postexposure prophylaxis for high-risk patients who cannot be vaccinated or who are not expected to respond to the vaccine (eg, immunocompromised patients).

5. For prophylaxis of individuals who will be exposed to avian influenza, in consultation with the local medical office of health.

6. As treatment of influenza-like illness in patients not expected to have developed a protective antibody response to vaccination (eg, frail and elderly persons or immunosuppressed persons).

7. As treatment for persons with a high risk of morbidity and mortality who have not received the influenza vaccine for that influenza season.

8. For unvaccinated persons who provide care for people at high risk during an outbreak, until two weeks postvaccination of the caregiver.

9. As treatment for influenza-like illness during a pandemic until the population can be immunized with an effective vaccine.

10. For the control of influenza outbreaks (treatment and/or prophylaxis) among high-risk residents of institutions.

\section{PROPHYLACTIC EFFICACY}

\section{Children}

The prophylactic efficacy of amantadine has been evaluated in four placebo-controlled trials in children eight years of age and older (Table 1) (8). Amantadine reduced the incidence of laboratory-confirmed influenza illness by $80 \%$ (median; range $69 \%$ to $92 \%$ ).
Zanamivir prophylactic efficacy has not been evaluated in controlled trials in children. However, children five to 17 years of age were included in a placebo-controlled trial of zanamivir for postexposure prophylaxis of influenza in families (9). All families had two to five members, including at least one child five to 17 years of age. Zanamivir reduced the incidence of laboratory-confirmed illness from 18\% (30 of 168 families) to 4\% (six of 169 families), a statistically significant difference. Tolerance was comparable between zanamivir and placebo therapy. Among asthmatics requiring regular use of medication, exacerbation occurred in $11 \%$ in the placebo group and $6 \%$ in the zanamivir groups (10).

In a similar study of oseltamivir (11), postexposure prophylaxis (75 mg daily for seven days) reduced the incidence of laboratory-confirmed influenza in families from 23\% (18 of 79 households treated with placebo) to $3.6 \%$ (three of 84 households treated with oseltamivir), a protective efficacy of $84 \%(\mathrm{P}<0.001)$. Each household consisted of two to eight contacts at least 12 years of age. Amantadine and oseltamivir are approved for influenza prophylaxis in children aged one year or older and children aged 13 years and older, respectively.

\section{Adults}

Double-blind, placebo-controlled trials of influenza antiviral drugs for the prophylaxis of influenza have demonstrated prophylactic efficacy ranging from 3\% - when rimantadine was used to prophylax the household contacts of index cases treated with rimantadine, whereupon resistant virus was transmitted (12) - to $100 \%$ - when the index case was not treated with amantadine (Table 1) (13-20). Both zanamivir and oseltamivir prevent influenza $\mathrm{A}$ and $\mathrm{B}$, with an efficacy relative to placebo of $56 \%$ (14) to $90 \%(15)$.

WHICH PROPHYLACTIC REGIMENS ARE BEST? There are no head to head trials comparing amantadine with the NAIs, but the prophylactic efficacy of the two classes of agents is comparable. One should consider the potential side effects, cost, laboratory monitoring, and particularly the chance of virus resistance, when choosing a regimen. The doses for prophylaxis are listed in Table 2 . The problem of the emergence of influenza viruses that are resistant to amantadine in nursing homes (21) and in households where an index case has been treated with amantadine (and the family contacts therefore ineffectively prophylaxed with rimantadine $[12,14]$ ) has been demonstrated. However, as noted in the 2004 recommendations of the Centers for Disease Control and Prevention (CDC) Advisory Committee on Immunization Practices (22), the effect of amantadine and rimantadine resistance on the control of influenza has not been well studied. Swedish recommendations (23) published in a 2003 report state that amantadine was withdrawn in Sweden in part because of the rapid emergence of resistance, as well as the "high frequency of central nervous system [CNS] side effects". With regard to the latter reason, rimantadine would likely be more tolerable, but neither of the ion channel blockers have any effect on influenza B. Furthermore, amantadine/rimantadine resistance has been steadily increasing worldwide (24), and H3N2 isolates from the 2005/2006 season were $91 \%$ and $89 \%$ amantadineresistant in the United States (25) and Canada (Y Li, Public Health Agency of Canada, personal communication), respectively. Zanamivir is the recommended drug for the treatment of influenza B in the Swedish recommendations, but this distinction 
TABLE 1

Results of selected randomized, double-blind, controlled trials of antiviral drug prophylaxis of influenza

\begin{tabular}{|c|c|c|c|c|c|}
\hline $\begin{array}{l}\text { Author, } \\
\text { reference }\end{array}$ & Drug & Study population and setting & $\begin{array}{l}\text { Influenza } \\
\text { virus type }\end{array}$ & PE & Comments \\
\hline $\begin{array}{l}\text { Oker-Blom } \\
\text { et al, } 1970 \text { (16) }\end{array}$ & $\begin{array}{l}\text { Amantadine } 100 \mathrm{mg} \text { twice } \\
\text { daily } \times 5 \text { weeks }\end{array}$ & $\begin{array}{l}\text { Healthy medical students during } \\
\text { a community influenza outbreak. } \\
\text { Amantadine }(n=192) \text {, placebo }(n=199)\end{array}$ & $\mathrm{A}(\mathrm{H} 3 \mathrm{~N} 2)$ & $66 \%$ & $\begin{array}{l}\text { PE with pre-outbreak } \mathrm{HI} \text { titre } \\
\quad \leq 1: 10=72 \% \\
\text { PE with pre-outbreak HI titre } \\
\geq 1: 20=58 \%\end{array}$ \\
\hline $\begin{array}{l}\text { Dolin et al, } \\
1982 \text { (17) }\end{array}$ & $\begin{array}{l}\text { Amantadine } 100 \mathrm{mg} \text { twice } \\
\text { daily } \times 4 \text { weeks } \\
\text { Rimantadine } 100 \mathrm{mg} \text { twice } \\
\text { daily } \times 4 \text { weeks }\end{array}$ & $\begin{array}{l}\text { Healthy volunteers } 18 \text { to } 45 \text { years } \\
\text { of age during a community influenza } \\
\text { outbreak. Amantadine ( } n=145) \\
\text { rimantadine }(n=147) \text {, placebo }(n=148)\end{array}$ & $\mathrm{A}(\mathrm{H} 3 \mathrm{~N} 2)$ & $91 \%$ & $\begin{array}{l}\text { CNS side effects (insomnia, } \\
\text { jitteriness, poor concentration); } \\
13 \% \text { amantadine, } \\
6 \% \text { rimantadine, } \\
4 \% \text { placebo }\end{array}$ \\
\hline $\begin{array}{l}\text { Payler and } \\
\text { Purdham, } \\
1984(18)^{*}\end{array}$ & $\begin{array}{l}\text { Amantadine } 100 \mathrm{mg} \text { once } \\
\text { daily }\end{array}$ & $\begin{array}{l}\text { Prophylaxis of } 13 \text { - to } 19 \text {-year-old } \\
\text { male students during a boarding } \\
\text { school influenza outbreak. } \\
\text { Amantadine }(n=21) \text {, control }(n=30)\end{array}$ & $\mathrm{A}(\mathrm{H} 3 \mathrm{~N} 2)$ & $90 \%$ & $\begin{array}{l}\text { No reported side effects at the } \\
100 \mathrm{mg} \text { per day dose }\end{array}$ \\
\hline $\begin{array}{l}\text { Galbraith et al, } \\
1969 \text { (13) }\end{array}$ & $\begin{array}{l}\text { Amantadine } 100 \mathrm{mg} \text { twice } \\
\text { daily }\end{array}$ & $\begin{array}{l}\text { Postexposure prophylaxis of } \\
\text { family contacts of a nonamantadine- } \\
\text { treated index case. Amantadine }(n=102) \text {, } \\
\text { placebo }(n=100)\end{array}$ & $\mathrm{A}(\mathrm{H} 3 \mathrm{~N} 2)$ & $100 \%$ & $\begin{array}{l}\text { No significant differences in } \\
\text { reported side effects compared } \\
\text { with placebo }\end{array}$ \\
\hline $\begin{array}{l}\text { Hayden et al, } \\
1989(12)\end{array}$ & $\begin{array}{l}\text { Rimantadine } 100 \mathrm{mg} \\
\text { twice daily } \times 10 \text { days }\end{array}$ & $\begin{array}{l}\text { Postexposure prophylaxis of } \\
\text { family contacts of a } \\
\text { rimantadine-treated index case. } \\
\text { Amantadine }(n=61) \text {, placebo }(n=54)\end{array}$ & $\begin{array}{c}\mathrm{A}(\mathrm{H} 1 \mathrm{~N} 1 \\
\text { and } \mathrm{H} 3 \mathrm{~N} 2)\end{array}$ & $3 \%$ & $\begin{array}{l}\text { Rimantadine-resistant H3N2 virus } \\
\text { shed by treated case-infected } \\
\text { contacts }\end{array}$ \\
\hline $\begin{array}{l}\text { Monto et al, } \\
1999 \text { (19) }\end{array}$ & $\begin{array}{l}\text { Zanamivir } 10 \mathrm{mg} \text { inhaled } \\
\text { daily } \times 28 \text { days }\end{array}$ & $\begin{array}{l}\text { Pre-exposure prophylaxis of } \\
\text { healthy volunteers during a } \\
\text { community influenza outbreak. } \\
\text { Zanamivir }(n=554) \text {, placebo }(n=553)\end{array}$ & $\mathrm{A}(\mathrm{H} 3 \mathrm{~N} 2)$ & $\begin{array}{l}67 \% \\
\text { febrile } \\
\text { influenza } 81 \%\end{array}$ & $\begin{array}{l}\text { No bronchospasm reported in } \\
\text { the zanamivir group, versus } \\
\text { two of } 655 \text { persons in the } \\
\text { placebo group }\end{array}$ \\
\hline $\begin{array}{l}\text { Hayden et al, } \\
1989(12)\end{array}$ & $\begin{array}{c}\text { Zanamivir } 10 \mathrm{mg} \text { inhaled } \\
\text { once daily for } 10 \text { days }\end{array}$ & $\begin{array}{l}\text { Postexposure prophylaxis of } \\
\text { family contacts of a } \\
\text { zanamivir-treated index case. } \\
\text { Zanamivir }(n=414) \text {, placebo }(n=423)\end{array}$ & $\begin{array}{l}\text { A } \\
B\end{array}$ & $\begin{array}{l}77 \% \\
68 \%\end{array}$ & $\begin{array}{l}\text { Side effects } 3 \% \text { to } 5 \% \text {; not } \\
\text { statistically different than } \\
\text { placebo }\end{array}$ \\
\hline $\begin{array}{l}\text { Hayden et al, } \\
1999(20)\end{array}$ & $\begin{array}{l}\text { Oseltamivir } 75 \text { mg orally } \\
\text { once or twice daily } \\
\times 6 \text { weeks }\end{array}$ & $\begin{array}{l}\text { Pre-exposure prophylaxis of } \\
\text { healthy volunteers during a } \\
\text { community influenza outbreak. } \\
\text { Oseltamivir } 75 \text { mg daily }(n=520) \\
\text { oseltamivir } 75 \text { mg twice daily }(n=520) \text {, } \\
\text { placebo }(n=519)\end{array}$ & A & $\begin{array}{l}74 \% \text { (twice } \\
\text { daily dose); } \\
90 \% \text { (once } \\
\text { daily dose) }\end{array}$ & $\begin{array}{l}\text { Side effects: Nausea } 10 \% \text { to } 12 \% \\
\text { more than placebo; } \\
\text { vomiting } 1.7 \% \text { more than } \\
\text { placebo. No differences in } \\
\text { discontinuation of drug } \\
\text { over } 6 \text { weeks }\end{array}$ \\
\hline $\begin{array}{l}\text { Welliver et al, } \\
2001 \text { (11) }\end{array}$ & $\begin{array}{l}\text { Oseltamivir } 75 \mathrm{mg} \text { orally } \\
\text { once daily } \times 7 \text { days }\end{array}$ & $\begin{array}{l}\text { Postexposure prophylaxis of } \\
\text { family contacts of a } \\
\text { nonoseltamivir-treated index case. } \\
\text { Oseltamivir }(n=497) \text {, placebo }(n=465)\end{array}$ & $\begin{array}{c}A(H 3 N 2) \\
B\end{array}$ & $\begin{array}{l}84 \% \\
78.5 \%\end{array}$ & \\
\hline $\begin{array}{l}\text { Peters et al, } \\
2001(15)\end{array}$ & $\begin{array}{l}\text { Oseltamivir } 75 \text { mg orally } \\
\text { once daily } \times 6 \text { weeks }\end{array}$ & $\begin{array}{l}\text { Persons } \geq 65 \text { years of age living in residential } \\
\text { homes or sheltered accommodation } \\
\text { for seniors, } 80 \% \text { of whom had received } \\
\text { influenza vaccine. Oseltamivir ( } n=276) \text {, } \\
\text { placebo }(n=272)\end{array}$ & I & $90 \%$ & $\begin{array}{l}78 \% \text { reduction in complications. } \\
\text { Side effects: Headache } 3 \% \\
\text { more than placebo; nausea } 1 \% \\
\text { more than placebo; vomiting } \\
\text { less than } 2 \% \text { of all subjects }\end{array}$ \\
\hline $\begin{array}{l}\text { Hayden et al, } \\
2004(14)^{\dagger}\end{array}$ & $\begin{array}{l}\text { Oseltamivir postexposure } \\
\text { prophylaxis with and } \\
\text { without treatment of the } \\
\text { index case }\end{array}$ & $\begin{array}{l}\text { Family contacts of an index case } \\
\text { of influenza during a naturally } \\
\text { occurring influenza outbreak. } \\
\text { Oseltamivir }(n=410) \text {, controls }(n=402)\end{array}$ & A & $\begin{array}{l}56 \% \text { (index } \\
\text { cases treated) }\end{array}$ & \\
\hline
\end{tabular}

${ }^{*}$ This study was randomized but not blinded and had no placebo; ${ }^{\dagger}$ Controls received oseltamivir treatment if illness developed. CNS Central nervous system; HI Hemagglutination inhibition; PE Protective efficacy

is not made in the CDC recommendations. Despite comparable efficacy in the trials listed in Table 1, Sweden has decided to recommend oseltamivir for prophylaxis over zanamivir, possibly because of rare reports of bronchospasm and 'throat tightness' with zanamivir.

\section{TREATMENT WITH ANTIVIRAL DRUGS}

Clinical characteristics and diagnosis of influenza

Proper diagnosis of influenza is important because the current influenza antivirals have no effect on other respiratory virus infections. Influenza illness in older children and adolescents is 
TABLE 2

Recommended doses of antiviral agents for the prevention of influenza in children and adults

\begin{tabular}{|c|c|c|c|c|}
\hline Drug & Viruses prevented & Age or weight & Dose & Evidence grade* \\
\hline \multirow[t]{4}{*}{ Amantadine } & Influenza A & $<1$ year of age & No data available & - \\
\hline & & $1-9$ years of age & $5 \mathrm{mg} / \mathrm{kg} /$ day to maximum & Evidence grade for tolerance only IA \\
\hline & & $10-64$ years of age & $200 \mathrm{mg}$ once daily, or divided twice daily ${ }^{\dagger}$ & Evidence grade for tolerance only IA \\
\hline & & $\geq 65$ years of age & 100 mg once daily & - \\
\hline \multirow{2}{*}{ Zanamivir ${ }^{\ddagger}$} & & 18 to 69 years of age & $10 \mathrm{mg}$ once daily & Evidence grade $\mathrm{IA}$ \\
\hline & & $\geq 70$ years of age & $10 \mathrm{mg}$ once daily & Evidence grade IB \\
\hline \multirow[t]{3}{*}{ Oseltamivir $¥ \S$} & Influenza A and B & $<1$ year of age & No data available & - \\
\hline & & $>1$ year of age and $\leq 15 \mathrm{~kg}$ & $30 \mathrm{mg}$ once daily & Evidence grade IA \\
\hline & & $>65$ years of age & $75 \mathrm{mg}$ once daily & Evidence grade IA \\
\hline
\end{tabular}

*Data from reference $59 ;+100 \mathrm{mg}$ once daily for those with seizure disorder; $¥$ Oseltamivir is not licensed for prophylaxis in individuals younger than 13 years of age. Zanamivir is not licensed for prophylaxis; §Oseltamivir dose for renal failure: A dose reduction is required if the creatinine clearance is less than $30 \mathrm{~mL} / \mathrm{min}$. For adults, give $75 \mathrm{mg}$ every other day for prophylaxis (52). A corresponding adjustment is recommended for children. NOTE: Duration of exposure: Seasonal prophylaxis - usually six to eight weeks; Postexposure household prophylaxis - 10 days; Institutional exposure - until eight days after onset of last case; After influenza vaccine - until two weeks after appropriate vaccination (one or two doses)

classically characterized by the sudden onset of fever and chills and is accompanied by headache, malaise, myalgia and nonproductive cough (26). As the illness evolves, respiratory tract signs become prominent, with throat soreness, nasal congestion, rhinitis and a worsening cough. Influenza in younger children may be manifested as upper respiratory tract infection with a few additional symptoms or as a febrile illness with few respiratory symptoms. In infants, influenza may result in a clinical picture that mimics sepsis, and can also present as croup, bronchiolitis and pneumonia. A well-recognized feature in some patients is acute myositis with calf tenderness and refusal to walk. This feature is particularly seen in children with influenza B infection. Other manifestations of influenza illness include Reye's syndrome and CNS infection. Otitis media is a complication in $10 \%$ of children (27).

In adults, the typical influenza syndrome is an acute onset of fever with subsequent tracheobronchitis, although any upper respiratory infection syndrome can occur. Serious infection complications include bacterial pneumonia and, rarely, primary influenza virus pneumonia.

Treatment of influenza reduces the duration and severity of acute symptoms. Amantadine or rimantadine treatment has been associated, in a period as short as three days, with excretion of amantadine-resistant virus (despite a clinical response by the patient), which may infect close contacts (12).

Emergence of resistance to the NAI oseltamivir has been reported in $18 \%$ of children being treated with this agent, (28). Development of zanamivir-resistant strains has been described in immunocompromised patients $(29,30)$. It has been suggested that neuraminidase resistance mutations result in a virus that is less fit (31). Person-to-person transmission of oseltamivir-resistant strains is suggested in one report (32), but otherwise appears to be quite rare.
Influenza antivirals should only be used for treatment when a patient demonstrates acute clinical symptoms compatible with influenza at a time when public health agencies report that influenza is prevalent in the community, or when influenza is specifically diagnosed by rapid tests at any time. Zanamivir and oseltamivir should not be used if the duration of symptoms has been longer than $48 \mathrm{~h}$ because effectiveness is negligible after this time, unless the patient has significant immunodeficiency and has progressive respiratory disease

Antiviral agents could potentially reduce the incidence of major, life-threatening secondary complications of influenza illness, including bacterial pneumonia. In one study (33), antiviral compounds were tested in a mouse model of secondary pneumococcal pneumonia after influenza. Oseltamivir therapy improved survival in mice from $0 \%$ to $75 \%$, even when therapy was delayed for up to five days after infection with influenza virus. Interestingly, treatment with rimantadine had no effect on survival. In addition, treatment with ampicillin cleared infection but did not improve survival unless oseltamivir treatment was also administered. The mechanism of the effect is that oseltamivir prevents neuraminidaseinduced exposure of epithelial cell ligands for Streptococcus pneumoniae.

Diagnosing influenza illness by clinical criteria in adults is difficult and even more problematic in children. Among nonimmunized young healthy adults, the combination of a fever of $37.8^{\circ} \mathrm{C}$ or higher plus at least one respiratory symptom (sore throat, cough or nasal symptoms) and one constitutional symptom (myalgia, headache, sweats, chills or fatigue) are predictive of influenza by laboratory testing in $60 \%$ to $71 \%$ of cases $(34,35)$. The presence of cough and a fever of $37.8^{\circ} \mathrm{C}$ or higher has a positive predictive value of $86.8 \%$ for a laboratory-confirmed diagnosis of influenza, although the negative predictive value is poor at $39.3 \%$ (36). 
TABLE 3

Randomized treatment trials of neuraminidase inhibitors involving children with influenza virus infections

\begin{tabular}{|c|c|c|c|c|}
\hline $\begin{array}{l}\text { Authors and } \\
\text { reference }\end{array}$ & Study design and study arms & $\begin{array}{l}\text { Target population } \\
\text { and sample size }\end{array}$ & $\begin{array}{l}\text { Influenza } \\
\text { virus } \\
\text { type }\end{array}$ & Outcomes \\
\hline \multirow[t]{4}{*}{$\begin{array}{l}\text { Hayden et al, } \\
1997(43)\end{array}$} & Randomized double-blind study design & Age $\geq 13$ years & $A$ and $B$ & $\begin{array}{l}\text { Active drug arms reduced median duration } \\
\text { of symptoms by } 1 \text { day }(P=0.05 \text { for inhaled } \\
\text { and } P=0.02 \text { for inhaled }+ \text { intranasal })\end{array}$ \\
\hline & - Zanamivir $10 \mathrm{mg}$ by oral inhalation BID for 5 days & $\mathrm{n}=85$ inhaled & & \\
\hline & $\begin{array}{l}\text { - Zanamivir } 10 \mathrm{mg} \text { by oral inhalation BID for } 5 \text { days } \\
+ \text { intranasal zanamivir }\end{array}$ & $\mathrm{n}=88$ inhaled + intranasal & & $\begin{array}{l}\text { Adverse events: } 18 \% \text { inhaled, } 23 \% \text { inhaled } \\
+ \text { intranasal and } 25 \% \text { placebo }(P=N S)\end{array}$ \\
\hline & - Placebo & $\mathrm{n}=89$ & & \\
\hline $\begin{array}{l}\text { MIST Study } \\
\text { Group, }\end{array}$ & Randomized double-blind study design & Age $\geq 12$ years & $A$ and $B$ & $\begin{array}{l}\text { Active drug reduced median duration of } \\
\text { symptoms by } 1.5 \text { days }(P=0.004)\end{array}$ \\
\hline $1998(44)$ & $\begin{array}{l}\text { - Zanamivir } 10 \mathrm{mg} \text { by oral inhalation BID for } 5 \text { days } \\
\text { - Placebo }\end{array}$ & $\begin{array}{l}n=161 \\
n=160\end{array}$ & & Adverse events profile similar to placebo \\
\hline \multirow[t]{3}{*}{$\begin{array}{l}\text { Makela et al, } \\
2000(57)\end{array}$} & Randomized double-blind study design & Age 12 to 81 years & $A(H 3 N 2)$ and $B$ & $\begin{array}{l}\text { Active drug reduced median duration of } \\
\text { symptoms by } 2.5 \text { days }(P=0.001)\end{array}$ \\
\hline & - Zanamivir $10 \mathrm{mg}$ by oral inhalation BID for 5 days & $n=136$ & & Adverse events profile similar to placebo \\
\hline & - Placebo & $n=141$ & & \\
\hline \multirow[t]{4}{*}{$\begin{array}{l}\text { Hedrick et al, } \\
2000 \text { (58) }\end{array}$} & Randomized double-blind study design & Age 4 to 12 years & $A$ and $B$ & $\begin{array}{l}\text { Active drug reduced median duration of } \\
\text { symptoms by } 1.25 \text { days }(P=0.001) \text {. }\end{array}$ \\
\hline & & & & Similar rates of adverse events \\
\hline & - Zanamivir $10 \mathrm{mg}$ by oral inhalation BID for 5 days & $n=164$ & & No drug resistance \\
\hline & - Placebo & $n=182$ & & \\
\hline \multirow[t]{3}{*}{$\begin{array}{l}\text { Whitley et al, } \\
2001(40)\end{array}$} & Randomized double-blind study design & Age 1 to 12 years & $A$ and $B$ & $\begin{array}{l}\text { Active drug reduced median duration of } \\
\text { illness by } 36 \text { h }(P=0.0001) \text {. Reduced } \\
\text { otitis media by } 44 \%\end{array}$ \\
\hline & - Oseltamivir 2 mg/kg po BID (maximum 100 mg po BID) & $n=217$ & & $\begin{array}{l}\text { Emesis: } 14.3 \% \text { oseltamivir versus } \\
8.5 \% \text { placebo; } 5.5 \% \text { of isolates resistant } \\
\text { to oseltamivir }\end{array}$ \\
\hline & - Placebo & $n=235$ & & \\
\hline \multirow[t]{2}{*}{$\begin{array}{l}\text { Whitley et al, } \\
2000(49)^{\star}\end{array}$} & - Oseltamivir 2 mg/kg po BID (maximum 100 mg po BID) & $\begin{array}{l}\text { Age } 6 \text { to } 12 \text { years with } \\
\text { asthma }(n=334 ; n=179 \\
\text { with laboratory-confirmed } \\
\text { influenza) }\end{array}$ & A and B & $\begin{array}{l}\text { Active drug reduced median duration of } \\
\text { illness by } 10.3 \mathrm{~h}(\mathrm{P}=0.54) \text {. Active drug } \\
\text { reduced asthma exacerbations } \\
\text { by } 36 \%(\mathrm{P}=0.0143)\end{array}$ \\
\hline & - Placebo & & & \\
\hline
\end{tabular}

${ }^{*}$ Abstract; limited details available. BID Twice daily; NS Not significant; po Orally

Among immunized patients 60 years of age and older, the combination of fever, coughing and acute onset have a predictive value of $44 \%$ for a laboratory-confirmed diagnosis of influenza (37).

The sensitivity and specificity of the clinical diagnosis of influenza in individuals at high risk of premature death and the development of complications of influenza due to older age or the presence of significant comorbid medical conditions or prior immunization are not known.

In children, the clinical picture may be even less specific than in adults because children cannot articulate their symptoms as readily. Exclusive pediatric studies evaluating the sensitivity and specificity of a clinical diagnosis of influenza compared with a laboratory gold standard are limited (38). In one study (39), fever, cough and rhinorrhea were the most common clinical manifestations, but these are all nonspecific. Almost one-third of pediatric patients seen in an emergency department during an epidemic had laboratory-confirmed influenza. Coexisting outbreaks of respiratory syncytial virus and influenza are not uncommon.
Point of care or rapid laboratory tests to confirm the clinical diagnosis of influenza are sensitive (69\% to $89 \%)$ and specific ( $83 \%$ to $99 \%$ ) in children, but much less so in adults. Children shed viruses in higher titre and for longer duration than adults. Rapid tests could be used to confirm the clinical diagnosis in children seen during an epidemic, and to add to the evidence supporting a decision to prescribe anti-influenza drugs and to not prescribe antibiotics. Alternatively, they could be used simply to affirm that influenza is circulating in the community. The exact role for such tests remains unclear and will depend on the peculiar economics of pediatric care in a region, as well as the operating characteristics of the test.

\section{Treatment efficacy}

Children: Clinical trials of the NAIs in children have shown that the duration of acute symptoms are reduced by $36 \mathrm{~h} \mathrm{com-}$ pared with placebo, incidence of otitis media is reduced by $44 \%$ and the use of antibiotic therapy is reduced by $25 \%$ (Table 3) (40). 
TABLE 4

Results of selected randomized, double-blind, placebo-controlled clinical trials of antiviral drug therapy of influenza in adults

\begin{tabular}{|c|c|c|c|c|c|c|}
\hline Drug & Study setting & Population & $\begin{array}{l}\text { Influenza } \\
\text { virus type }\end{array}$ & $\begin{array}{l}\text { Duration } \\
\text { of symptoms }\end{array}$ & $\begin{array}{l}\text { Resumption } \\
\text { of normal } \\
\text { activity }\end{array}$ & $\begin{array}{l}\text { Somplication } \\
\text { rate }\end{array}$ \\
\hline $\begin{array}{l}\text { Amantadine } 100 \mathrm{mg} \text { bid } \\
\text { for } 10 \text { days }(41)\end{array}$ & Naturally-occurring influenza & $\begin{array}{l}\text { Prison volunteers. } \\
\text { Amantadine }(n=54) \text {, } \\
\text { placebo }(n=48)\end{array}$ & A & $\begin{array}{l}\text { (reduction of fever) } \\
D=96 \mathrm{~h} \\
P=120 \mathrm{~h}\end{array}$ & NR & NR \\
\hline $\begin{array}{l}\text { Amantadine } 100 \mathrm{mg} \text { bid } \\
\text { or rimantadine } 100 \mathrm{mg} \\
\text { bid for } 10 \text { days }(42)\end{array}$ & Wild-type influenza & $\begin{array}{l}\text { Selected families. } \\
\text { Amantadine }(n=23), \\
\text { Rimantadine }(n=24) \text {, } \\
\text { placebo }(n=47)\end{array}$ & A & $\begin{array}{l}1.6 \text { to } 2.5 \text { days } \\
\text { less than placebo }\end{array}$ & $\begin{array}{l}1.5 \text { days less } \\
\text { than placebo }\end{array}$ & NR \\
\hline $\begin{array}{l}\text { Zanamivir } 10 \text { mg by } \\
\text { inhaler bid or } \\
\text { qid for } 5 \text { days (34) }\end{array}$ & $\begin{array}{l}\text { Wild type outbreak treated } \\
<48 \mathrm{~h} \text { after symptoms started. } \\
\text { Influenza attack rate }=57 \% \text {. } \\
\text { Setting: North America } \\
\text { and Europe }\end{array}$ & $\begin{array}{l}\text { Previously healthy adults } \\
\text { and young adults. } \\
\text { Zanamivir bid ( } n=419), \\
\text { Zanamivir qid ( } n=415) \text {, } \\
\text { placebo }(n=422)\end{array}$ & $\begin{array}{l}56 \% A \\
44 \% B\end{array}$ & $\begin{array}{l}\text { ITT: } \\
\qquad \begin{array}{l}D=5.3 \text { days } \\
P=6.0 \text { days } \\
\text { Confirmed influenza: } \\
D=5.1 \text { days } \\
P=7 \text { days }\end{array}\end{array}$ & $\begin{array}{l}\text { After } 5.5 \text { days: } \\
\qquad \begin{array}{l}D=54 \% \\
P=45 \%\end{array} \\
\text { Confirmed influenza: } \\
D=4 \text { days } \\
P=5 \text { days }\end{array}$ & $\begin{array}{l}\text { Confirmed } \\
\text { influenza: } \\
\begin{array}{c}D=8 \% \\
P=12 \%\end{array}\end{array}$ \\
\hline $\begin{array}{l}\text { Zanamivir } 10 \mathrm{mg} \text { by inhaler } \\
\text { bid for } 5 \text { days (44) }\end{array}$ & $\begin{array}{l}\text { Wild type outbreak treated } \\
\leq 48 \mathrm{~h} \text { after start of symptoms. } \\
\text { Influenza attack rate }=71 \% \text {. } \\
\text { Setting: Southern hemisphere }\end{array}$ & $\begin{array}{l}\text { General adult and young } \\
\text { adult community of low- } \\
\text { and high-risk }(17 \%) \text { patients. } \\
\text { Zanamivir }(n=227) \text {, } \\
\text { placebo }(n=228)\end{array}$ & $\begin{array}{l}67 \% \mathrm{~A} \\
33 \% \mathrm{~B}\end{array}$ & $\begin{array}{l}D=4.5 \text { days } \\
P=6 \text { days }\end{array}$ & $\begin{array}{l}D=7 \text { days } \\
P=9 \text { days }\end{array}$ & $\begin{array}{l}\text { High risk } \\
\text { patients: } \\
\begin{aligned} D=14 \% \\
P=46 \%\end{aligned}\end{array}$ \\
\hline $\begin{array}{l}\text { Zanamivir } 10 \mathrm{mg} \text { by inhaler } \\
\text { bid for } 5 \text { days ( } 57 \text { ) }\end{array}$ & $\begin{array}{l}\text { Wild type outbreak treated } \\
\leq 48 \mathrm{~h} \text { after symptom onset. } \\
\text { Influenza attack rate }=78 \% \text {. } \\
\text { Setting: Europe }\end{array}$ & $\begin{array}{l}\text { Previously healthy adults } \\
\text { and young adults plus } \\
\text { high-risk patients }(9 \%) \text {. } \\
\text { Zanamivir ( } n=174) \text {, } \\
\text { placebo }(n=182)\end{array}$ & $\begin{array}{l}96 \% A \\
4 \% B\end{array}$ & $\begin{array}{l}D=5 \text { days } \\
P=7.5 \text { days }\end{array}$ & $\begin{array}{l}D=7 \text { days } \\
P=8.5 \text { days }\end{array}$ & $\begin{array}{l}D=34 \% \\
P=23 \%\end{array}$ \\
\hline $\begin{array}{l}\text { Zanamivir } 10 \mathrm{mg} \text { by inhaler } \\
\text { bid for } 5 \text { days (43) }\end{array}$ & $\begin{array}{l}\text { Wild type outbreak treated } \\
\leq 48 \mathrm{~h} \text { after symptom onset. } \\
\text { Influenza attack rate }=63 \% \text {. } \\
\text { Setting: North America and } \\
\text { Europe }\end{array}$ & $\begin{array}{l}\text { Healthy plus high-risk adult } \\
\text { and young adult patients. } \\
\text { Zanamivir }(n=132) \\
\text { placebo }(n=145)\end{array}$ & $\begin{array}{l}91 \% \mathrm{~A} \\
9 \% \mathrm{~B}\end{array}$ & $\begin{array}{l}\text { Overall ITT: } \\
\qquad \mathrm{D}=4 \text { days } \\
\mathrm{P}=7 \text { days } \\
\text { Significant difference } \\
\text { only for treatment }<30 \mathrm{~h} \\
\text { after illness onset }\end{array}$ & $\begin{array}{l}\text { After } 5.5 \text { days: } \\
\qquad \begin{array}{l}D=54 \% \\
P=45 \%\end{array}\end{array}$ & NR \\
\hline $\begin{array}{l}\text { Oseltamivir } 75 \text { mg bid } \\
\text { or } 150 \text { mg bid orally for } \\
5 \text { days ( } 35 \text { ) }\end{array}$ & $\begin{array}{l}\text { Wild type outbreak treated } \\
\leq 36 \mathrm{~h} \text { after symptom onset. } \\
\text { Influenza attack rate = } 66 \% \text {. } \\
\text { Setting: Worldwide }\end{array}$ & $\begin{array}{l}\text { Previously healthy } \\
\text { adults and young adults. } \\
\text { Oseltamivir } 75 \mathrm{mg} \mathrm{(}=243) \text {, } \\
\text { oseltamivir } 150 \mathrm{mg}(\mathrm{n}=245) \text {, } \\
\text { placebo }(n=238)\end{array}$ & $\begin{array}{l}97 \% \mathrm{~A} \\
3 \% \mathrm{~B}\end{array}$ & $\begin{array}{l}\text { ITT: } \\
D=4 \text { days } \\
P=4.8 \text { days } \\
\text { Confirmed influenza: } \\
D=3.6 \text { days } \\
P=4.9 \text { days }\end{array}$ & 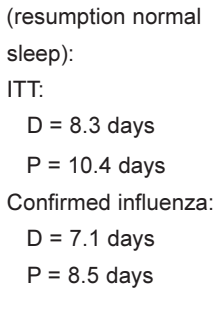 & $\begin{array}{l}\text { Less } \\
\text { antibiotic } \\
\text { use } \\
\text { in drug- } \\
\text { treated } \\
\text { group } \\
\text { compared } \\
\text { with } \\
\text { placebo }\end{array}$ \\
\hline $\begin{array}{l}\text { Oseltamivir } \\
75 \text { mg bid orally } \\
\text { for } 5 \text { days ( } 45)\end{array}$ & $\begin{array}{l}\text { Wild type outbreak treated } \\
\leq 36 \mathrm{~h} \text { after symptom onset. } \\
\text { Influenza attack rate }=60 \% \text {. } \\
\text { Setting: USA }\end{array}$ & $\begin{array}{l}\text { Previously healthy adults } \\
\text { and young adults }\end{array}$ & $\begin{array}{l}98 \% A \\
2 \% B\end{array}$ & $\begin{array}{l}\text { ITT: } \\
\qquad \begin{array}{l}\mathrm{D}=3.2 \text { days } \\
\mathrm{P}=4 \text { days } \\
\text { Confirmed influenza: } \\
\mathrm{D}=3 \text { days } \\
\mathrm{P}=4.3 \text { days }\end{array}\end{array}$ & $\begin{array}{l}\text { ITT: } \\
\qquad \begin{array}{l}D=7.2 \text { days } \\
P=9.6 \text { days } \\
\text { Confirmed influenza: } \\
\qquad \begin{array}{l}\text { D } \\
\text { P }\end{array}=9.5 \text { days } \\
\text { days }\end{array}\end{array}$ & $\begin{array}{l}D=6 \% \\
P=15 \%\end{array}$ \\
\hline
\end{tabular}

BID Twice daily; D Drug; ITT Intent to treat; NR Not recorded; P Placebo; QID Four times daily

Adults

In adults, randomized controlled trials of amantadine for the early treatment of influenza (within $24 \mathrm{~h}$ of the onset of fever) show a reduction in the severity of symptoms $(41,42)$. The more recent trials with zanamivir or oseltamivir started within $48 \mathrm{~h}$ of the onset of symptoms demonstrate a reduction in symptoms of fever and cough from 1.5 days to three days. Significant differences versus placebo were found only in those treated within $36 \mathrm{~h}$ of onset for oseltamivir and within $30 \mathrm{~h}$ of onset for zanamivir (Table 4) (34,35,43-45). The earlier the drugs are given after the onset of symptoms, the greater the reduction in duration of symptoms compared with placebo (46).

\section{THE USE OF INFLUENZA ANTIVIRALS IN PREGNANCY}

There are no published trials of the use of either M2 ion channel blockers or NAIs in pregnancy. The M2 blockers have both been shown to be teratogenic in animals in very high doses. If 
clinical circumstances warrant treatment or prophylaxis with an influenza antiviral agent in pregnant women, then zanamivir is likely the best choice because it is administered by inhalation and the systemic blood levels are comparatively lower than oseltamivir. The use of oseltamivir in lactating women should be decided on a case by case basis because it is not known whether the drug is excreted in human milk.

\section{SAFETY, TOLERANCE, AND DRUG INTERACTIONS AND FORMULATIONS}

\section{Amantadine}

Because amantadine has some CNS stimulatory properties, adults may complain of jitteriness, insomnia and, rarely, nightmares. These symptoms may be more common (up to 15\%) when the drug is used for several weeks for prophylaxis. Generally, however, and especially for the short time it is used for treatment (five days), it is as well tolerated as placebo. Toxicity may be greater if there is accumulation in patients with impaired renal excretory mechanisms, and this applies particularly to the elderly. To avoid this, it is recommended that elderly patients have serum creatinine levels measured at the beginning of treatment. Effective levels of amantadine are achieved in elderly patients given a reduced daily dose of $100 \mathrm{mg}$, rather than the usual dose of $200 \mathrm{mg}$ (47) (Tables 5 and 6).

In children, due to concerns regarding CNS toxicity caused by amantadine, plus the fact that it is only active against influenza $\mathrm{A}$, attention has been directed at developing the role of the NAIs.

Drug interactions: Concomitant administration of triamterene, hydrochlorothiazide and trimethoprim-sulfamethoxazole causes CNS toxicity in adults, presumably due to interference with renal elimination of amantadine, resulting in accumulation and toxicity.

Available formulations: Amantadine is available in $100 \mathrm{mg}$ capsules and as a $100 \mathrm{mg} / 10 \mathrm{~mL}$ syrup.

\section{NAIs}

Zanamivir: Zanamivir is administered as a powder by inhalation via a diskhaler. Because only $10 \%$ to $20 \%$ of the $10 \mathrm{mg}$ inhaled dose is absorbed in adults, systemic exposure is minimal. The drug is safe and well tolerated, as evidenced by studies revealing no adverse effects after intravenous injection of $1200 \mathrm{mg} /$ day to adult volunteers for five days. However, when
TABLE 5 National Advisory Committee on Immunization
recommended dosage adjustments of amantadine
according to creatinine clearance

\begin{tabular}{|c|c|c|}
\hline \multirow{2}{*}{$\begin{array}{l}\text { Creatinine } \\
\text { clearance } \\
\left(\mathrm{mL} / \mathrm{min} / 1.73 \mathrm{~m}^{2}\right)\end{array}$} & \multicolumn{2}{|l|}{ Dosage } \\
\hline & 10 to 64 years of age & $\geq 65$ years of age \\
\hline$\geq 80$ & $100 \mathrm{mg}$ twice daily & $100 \mathrm{mg}$ twice daily \\
\hline $60-79$ & $\begin{array}{l}\text { Alternating daily } \\
\text { doses of } 200 \mathrm{mg} \\
\text { and } 100 \mathrm{mg}\end{array}$ & $\begin{array}{l}\text { Alternating daily doses of } \\
100 \mathrm{mg} \text { and } 50 \mathrm{mg} \\
\text { or } 75 \mathrm{mg} \text { daily }\end{array}$ \\
\hline $40-59$ & $100 \mathrm{mg}$ once daily & $\begin{array}{l}100 \mathrm{mg} \text { every } 2 \text { days } \\
\text { or } 50 \mathrm{mg} \text { daily }\end{array}$ \\
\hline 30-39 & 200 mg twice weekly & $\begin{array}{l}100 \mathrm{mg} \text { twice weekly } \\
\text { or } 25 \mathrm{mg} \text { daily }\end{array}$ \\
\hline $20-29$ & $100 \mathrm{mg}$ three times weekly & $\begin{array}{l}50 \mathrm{mg} \text { three times weekly } \\
\text { or } 25 \mathrm{mg} \text { daily }\end{array}$ \\
\hline $10-19$ & $\begin{array}{l}\text { Alternating weekly doses } \\
\text { of } 200 \mathrm{mg} \text { and } 100 \mathrm{mg}\end{array}$ & $\begin{array}{l}\text { Alternating weekly doses } \\
\text { of } 100 \mathrm{mg} \text { and } 50 \mathrm{mg}\end{array}$ \\
\hline
\end{tabular}

Data from reference 2

administered as an oral inhaled powder, practitioners are advised nevertheless to be aware of bronchospasm in zanamivir-treated patients. One study (9) of once-daily inhaled zanamivir as prophylaxis of family members of index cases was unable to find an increased rate of asthma exacerbations in asthmatic contacts receiving zanamivir (6\%) versus placebo (11\%). Another double-blind, placebo-controlled trial of zanamivir treatment of influenza in patients 12 to 88 years of age (median 38 years of age) with asthma or chronic obstructive pulmonary disease did not find an increased incidence of bronchospasm in the zanamivir group (48). In fact, the morning and evening peak expiratory flow rates were significantly increased in the zanamivir group (10). Despite this evidence, there have been reports of acute bronchospasm in patients taking zanamivir; as a result, the Advisory Committee on Immunization Practices of the CDC advised caution in using zanamivir for asthmatic and chronic obstructive pulmonary disease patients and advised that the patient should have a short-acting bronchodilator available during treatment (22).

Drug interactions: Interactions between zanamivir and other drugs coadministered systemically are neither likely nor expected due to the trivial absorption of zanamivir after oral inhalation.

\section{TABLE 6}

Recommended doses of antiviral agents for the treatment of influenza in children and adults

\begin{tabular}{|c|c|c|c|c|}
\hline & \multicolumn{2}{|l|}{ Children } & \multicolumn{2}{|c|}{ Adults } \\
\hline & Age and/or weight & Dose & Age & Dose \\
\hline \multirow[t]{3}{*}{ Amantadine* } & 1 to 9 years of age & $5 \mathrm{mg} / \mathrm{kg} /$ day, max $150 \mathrm{mg} /$ day in two doses & 13 to 64 years of age & 100 mg twice daily \\
\hline & $\geq 10$ years of age and $<40 \mathrm{~kg}$ & $5 \mathrm{mg} / \mathrm{kg} /$ day in 2 doses & $\geq 65$ years of age & 100 mg/day \\
\hline & $\geq 10$ years of age and $\geq 40 \mathrm{~kg}$ & 200 mg/day in 2 doses & & \\
\hline \multirow[t]{4}{*}{ Oseltamivir ${ }^{\dagger}$} & 1 to 12 years of age and $\leq 15 \mathrm{~kg}$ & 30 mg twice daily & 13 to 64 years of age & 75 mg twice daily \\
\hline & 1 to 12 years of age and $>15 \mathrm{~kg}$ to $23 \mathrm{~kg}$ & 45 mg twice daily & $\geq 65$ years of age & 75 mg twice daily \\
\hline & 1 to 12 years of age and $>23 \mathrm{~kg}$ to $40 \mathrm{~kg}$ & 60 mg twice daily & & \\
\hline & 1 to 12 years of age and $>40 \mathrm{~kg}$ & 75 mg twice daily & & \\
\hline \multirow[t]{2}{*}{ Zanamivir } & 1 to 6 years of age & $\mathrm{N} / \mathrm{A}$ & 13 to 64 years of age & 10 mg twice daily \\
\hline & 7 to 12 years of age & $10 \mathrm{mg}$ twice daily & $\geq 65$ years of age & 10 mg twice daily \\
\hline
\end{tabular}

The usual duration of treatment is five days. A longer duration of therapy may be required in immunocompromised patients. *Amantadine dose adjustment required in renal failure (see Table 5); ${ }^{\dagger}$ Oseltamivir dose for renal failure: A reduction in oseltamivir dose is required if the creatinine clearance is less than $30 \mathrm{~mL} / \mathrm{min}$. In adults with a creatinine clearance $10 \mathrm{~mL} / \mathrm{min}$ to $30 \mathrm{~mL} / \mathrm{min}$, give $75 \mathrm{mg}$ once daily for treatment (56). A corresponding adjustment is recommended for children 
Available formulations: Zanamivir is supplied in 'Rotadisks' (GlaxoSmithKline, USA) with four blisters containing $5 \mathrm{mg}$ of powder each. Five Rotadisks are packaged with a Diskhaler inhalation device (GlaxoSmithKline, USA). Generally, children younger than seven years of age and incompetent adults are unlikely to reliably exhibit the proper coordination required to use this product. Children should use zanamivir only under adult supervision.

Oseltamivir: The incidence of nausea or vomiting was increased by $3 \%$ over placebo in the therapeutic trials of oseltamivir, and by $3 \%$ to $12 \%$ in the prophylaxis trials, but rates of discontinuation were low and not different between the two groups, which consisted mostly of adults. Nausea or vomiting occurred early during therapy, and then usually subsided despite continuation of the drug. No other side effects occurred significantly more frequently in oseltamivir recipients than in placebo recipients.

Published pediatric data on the safety and efficacy of oseltamivir exist for children one year of age and older $(49,50)$. Pharmacokinetic data (50) show that $2 \mathrm{mg} / \mathrm{kg}$ twice daily resulted in drug exposures within the range associated with tolerability and efficacy in adults who were administered approximately $1 \mathrm{mg} / \mathrm{kg}$ twice daily. A liquid formulation was shown in a randomized, placebo-controlled trial (49) to be safe and well accepted by healthy children one to 12 years of age and in children with asthma aged six to 12 years. In the placebocontrolled trial evaluating the therapeutic efficacy of oseltamivir in children one to 12 years of age, emesis occurred in $14.3 \%$ of children receiving oseltamivir $2 \mathrm{mg} / \mathrm{kg} /$ dose twice daily for 10 doses (maximum $100 \mathrm{mg} /$ dose) and in $8.5 \%$ of children receiving placebo. Discontinuation rates for oseltamivir $(1.8 \%)$ and placebo $(1.1 \%)$ due to adverse events were not significantly different (50).

The safety and efficacy of oseltamivir in infants younger than one year of age have not been established. This is clearly an area where additional research is needed. A caution was issued due to deaths observed in seven day-old mice receiving extremely high doses of the drug (51). The mice were fed a dose that was approximately 250 times the dose recommended for children. The concentrations of the prodrug in the brain were 1500 times those of the adult animals exposed to the same dose. Thus, it was thought than an immature bloodbrain barrier may have caused the toxicity in these animals. Based on the ages of the animals and the stage of development of their blood-brain barrier, the human equivalent was thought to be infants younger than one year of age. However, recent reports from Japan did not show CNS toxicity in infants younger than one year of age who were treated with oseltamivir $(52,53)$.

In November 2005, there were reports of neuropsychiatric events and deaths in Japanese children receiving oseltamivir. The United States Food and Drug Administration has reviewed the available information and has concluded that the increased reports of neuropsychiatric events in Japanese children are most likely related to an increased awareness of influenza-associated encephalopathy, increased access to oseltamivir in that population, and a coincident period of intensive monitoring of adverse events (54). They were not able to establish a causal relationship between oseltamivir and the reports of pediatric deaths. Of note, deaths occurred in children two years of age and older, but the ages of those with neuropsychiatric manifestations were not reported (55).
Drug interactions: Interactions during the coadministration of oseltamivir with other drugs are unlikely because it is eliminated largely unchanged into urine by glomerular filtration and renal tubular secretion by an anionic transporter and does not cause dose-related adverse effects, even at high doses.

Available formulations: Oseltamivir is available as $75 \mathrm{mg}$ capsules or as an oral suspension containing $12 \mathrm{mg} / \mathrm{mL}$.

\section{SUMMARY OF RECOMMENDATIONS}

With respect to the role of antiviral drugs for the treatment or prevention of influenza infection, the CPS and AMMI Canada recommend the following:

\section{Drugs for the prevention and treatment of influenza}

A. Amantadine is approved and recommended for the prevention (evidence grade IB) and treatment (evidence grade IB) of influenza A virus infection in individuals one year of age or older only if the strain in circulation is susceptible to amantadine.

B. Zanamivir is approved and recommended for the treatment of influenza $\mathrm{A}$ and $\mathrm{B}$ virus infection in individuals older than seven years of age (evidence grade IA). It may be used off-label for the prevention of influenza $A$ and $B$ virus infection in individuals aged five years or older (evidence grade IA).

C. Oseltamivir is approved for the prevention of influenza $A$ and $B$ virus infection in individuals 13 years of age or older (evidence grade IA). The drug is also approved for the treatment of influenza $A$ and $B$ virus infection in individuals one year of age or older (evidence grade IA). It may be used off-label for the prevention of influenza $A$ and $B$ virus infection in individuals aged one year and older (evidence grade IA). Based on current evidence, it should not be used in infants younger than one year of age (evidence grade IIID).

D. Given that there are no antivirals currently approved for use in infants younger than one year of age, the CPS and AMMI Canada strongly encourage research on this issue.

\section{Prevention of influenza}

Antiviral drugs are recommended as a substitute for immunization to prevent influenza in the situations outlined below. These strategies should be accompanied by the appropriate education and awareness to enable early access to antivirals.

A. When a vaccine that is effective against strain(s) of influenza circulating in the community is not available, and exposure and the risk of illness is considered to persist through the outbreak, amantadine, zanamivir or oseltamivir may be administered until a vaccine becomes available or the outbreak has subsided (so called 'seasonal prophylaxis') (evidence grade IB). The data shown in Table 1 illustrate that the experience with these three drugs for seasonal prophylaxis is not uniform across all age groups.

Because no comparative trials have been conducted to support the selection of one agent from among the 
group, the choice of which drug to administered will depend on other factors, such as virus susceptibility (eg, influenza A H5N1 is susceptible to NAIs but not M2 inhibitors), ease of dosing (zanamivir = oseltamivir $>>$ amantadine), tolerance (zanamivir $>$ oseltamivir $>>$ amantadine) and cost (amantadine $<$ zanamivir $=$ oseltamivir). Zanamivir is not easy to administer in young children or adults incapable of operating the inhalation device.

Prophylaxis may be continued until the outbreak has subsided (usually six to eight weeks). Alternatively, it may be discontinued if a vaccine has become available or if it is suspected that the individual has experienced (mild) influenza attenuated by chemoprophylaxis or has been shown to have been infected, based on laboratory testing demonstrating that subclinical influenza has occurred as demonstrated by culture, rapid antigen testing or polymerase chain reaction of respiratory secretions.

B. When vaccine is contraindicated, seasonal chemoprophylaxis (as discussed in recommendation IIA) may be considered (evidence grade IIIC). For example, when a high-risk individual has immediate-type hypersensitivity to egg protein, traces of which may be present in vaccines prepared in embryonated chicken eggs, or to some other substance in the vaccine formulation, chemoprophylaxis is recommended. The choice of drug will require consideration, at least, of the factors listed above (recommendation IIA). The duration of prophylaxis may be as described above (recommendation IIA).

C. When an immediate protective effect is required, chemoprophylaxis has been shown to be effective and well tolerated. Such a need may exist when:

- an outbreak is diagnosed in a closed institutional setting;

- an outbreak is diagnosed in the family setting; or

- when influenza is causing illness in the community, even as vaccine is being administered.

i) Prophylaxis in a closed institutional setting may be initiated when an outbreak is diagnosed (evidence grade IIB). An outbreak may be diagnosed if at least two residents develop acute influenza-like illness within $72 \mathrm{~h}$ of each other and have laboratory-proven influenza illness that confirms that influenza is being transmitted. All three drugs have been used for outbreak control in nursing homes. Zanamivir and oseltamivir may be preferable to amantadine (evidence grade IB).

Usually, chemoprophylaxis for outbreak control in an institution is administered for at least 10 days. Prophylaxis may be discontinued if at least eight days have elapsed since the onset of the last case of influenza in the unit. If new cases continue to appear, then prophylaxis will, by corollary, need to be continued so that this strategy could become, in effect, seasonal prophylaxis. ii) When influenza occurs in the family setting, postexposure chemoprophylaxis in unaffected members should be considered to reduce illness in the family (evidence grade IA).

Unaffected family members should be started on chemoprophylaxis as soon as possible after recognition of influenza-like illness in the index case. All three drugs are recommended for postexposure prophylaxis when the virus is susceptible. The duration of prophylaxis is usually seven to 10 days.

The index case may be treated with the recommended five-day course of zanamivir or oseltamivir, but not amantadine. Treatment of the index case with amantadine has resulted in failure of amantadine prophylaxis in other family members due to the rapid development of amantadine-resistant mutants in the treated index case. If amantadine is the only option available for the index case in a household, then it should not be used for prophylaxis for other family members.

iii) Chemoprophylaxis may be utilized to protect individuals until vaccine-induced immunity develops (evidence grade IIIB). Chemoprophylaxis should be continued for two weeks after appropriate vaccination (one or two doses). When vaccine that is expected to protect against a circulating strain causing illness in the community is coadministered, chemoprophylaxis should be continued until vaccine-induced immunity is likely to have developed. The time for vaccineinduced immunity to develop may be seven to 10 days if the virus strains in the vaccine are drift variants of strains that have been causing illness in one or more previous years, such that some heterologous immunity is likely to exist that can be boosted by the current vaccine.

Where the vaccine contains a virus arising as a result of antigenic shift (eg, a pandemic strain), vaccine-induced immunity may require two or more doses of vaccine. Chemoprophylaxis will need to be continued until it is probable that immunity has developed (most likely a duration of two to three weeks), as demonstrated by clinical trials.

D. When high-risk individuals have been immunized but the vaccine strain(s) poorly match one or both of the hemagglutinin and/or neuraminidase antigens of the circulating strain, seasonal chemoprophylaxis is recommended (evidence grade IIIB). The duration of prophylaxis will be as stated above.

E. When individuals are not likely to respond to vaccine because of an immunocompromised state due to drugs or disease, seasonal chemoprophylaxis is recommended (evidence grade IIIB). The duration of prophylaxis will be as stated in recommendation IIA. 


\section{Treatment of influenza illness}

In general, antiviral chemotherapy is recommended for individuals with severe illness and those most likely to develop complications or die prematurely as a result of influenza.

The duration of therapy is five days (longer therapy may be indicated in patients with severe immunodeficiency who remain symptomatic and virus positive).

A. When antiviral drugs are administered for the treatment of influenza A or B infection, it is recommended that amantadine not be prescribed because of the high probability of the emergence of resistance (evidence grade IA), with possible treatment failure (evidence IB) and spread to others receiving amantadine for prophylaxis (evidence grade IA).

Because there have been no studies directly comparing the relative efficacies and safety of zanamivir and oseltamivir, selecting one drug from among these agents will need to be based on such considerations as the ability to orally inhale zanamivir or the ability to tolerate its uncommon irritant effect on the tracheobronchial tree with resulting bronchospasm.

B. When zanamivir or oseltamivir are administered for the treatment of influenza, they should be started as soon as possible after the onset of symptoms (evidence grade IA) and within 48 h of symptoms.

C. When the patient has been symptomatic for more than $48 \mathrm{~h}$, it is recommended that antiviral therapy not be prescribed unless the patient is immunocompromised and has progressive respiratory infection (evidence grade IIIC).

D. For seriously ill patients, combination therapy with amantadine and an NAI may be considered (evidence grade IIIC).

E. For treatment of pregnant women ill with influenza, it is noted that none of the drugs listed above can be recommended because they have not been evaluated for efficacy or safety in pregnant women or approved for administration in these individuals (evidence grade IIIC). However, zanamivir is minimally bioavailable after oral administration. Thus, zanamivir administered by inhalation to pregnant women is unlikely to cause much fetal exposure. Hence, from the point of view of safety, it may be the drug of choice for administration to pregnant women (evidence grade IIIC).

\section{APPENDIX \\ Levels of evidence and strength of recommendations*}

\begin{tabular}{|c|c|}
\hline Level of evidence & Description \\
\hline I & Evidence obtained from at least one properly randomized controlled trial. \\
\hline II-1 & Evidence obtained from well-designed controlled trial without randomization. \\
\hline II-2 & $\begin{array}{l}\text { Evidence obtained from well-designed cohort or case-controlled analytical studies, preferably from more than one } \\
\text { centre or research group. }\end{array}$ \\
\hline II-3 & $\begin{array}{l}\text { Evidence obtained from comparisons between times and places, with or without the intervention. Dramatic results } \\
\text { in uncontrolled experiments could also be included in this category. }\end{array}$ \\
\hline III & $\begin{array}{l}\text { Opinions of respected authorities, based on clinical experience, descriptive studies or reports of expert } \\
\text { committees. }\end{array}$ \\
\hline Grade & Description \\
\hline A & There is good evidence to recommend the clinical preventive action. \\
\hline B & There is fair evidence to recommend the clinical preventive action. \\
\hline C & $\begin{array}{l}\text { The existing evidence is conflicting and does not allow a recommendation to be made for or against use of the } \\
\text { clinical preventive action; however, other factors may influence decision-making. }\end{array}$ \\
\hline $\mathrm{D}$ & There is fair evidence to recommend against the clinical preventive action. \\
\hline $\mathrm{E}$ & There is good evidence to recommend against the clinical preventive action. \\
\hline I & $\begin{array}{l}\text { There is insufficient evidence to make a recommendation; however, other factors may influence } \\
\text { decision-making. }\end{array}$ \\
\hline
\end{tabular}

*Data from reference 59

\section{REFERENCES}

1. Szucs TD. Medical economics in the field of influenza past, present and future. Virus Res 2004;103:25-30.

2. National Advisory Committee on Immunization. Canada Communicable Disease Report: Statement on Influenza Vaccination for the 2005-2006 Season.

<www.phac-aspc.gc.ca/publicat/ccdr-rmtc/05pdf/acs-dcc3106.pdf> (Version current at September 26, 2006).

3. Marra F, Marra CA, Stiver HG. A case for rimantadine to be marketed in Canada for prophylaxis of influenza A virus infection. Can Respir J 2003;10:381-8.
4. Centers for Disease Control and Prevention (CDC). Update: Influenza activity - United States and worldwide, May-October 2004. MMWR Morb Mortal Wkly Rep 2004;53:993-5.

5. Govorkova EA, Leneva IA, Goloubeva OG, Bush K, Webster RG. Comparison of efficacies of RWJ-270201, zanamivir, and oseltamivir against $\mathrm{H} 5 \mathrm{~N} 1, \mathrm{H} 9 \mathrm{~N} 2$, and other avian influenza viruses. Antimicrob Agents Chemother 2001;45:2723-32.

6. Leneva IA, Roberts N, Govorkova EA, Goloubeva OG, Webster RG. The neuraminidase inhibitor GS4104 (oseltamivir phosphate) is efficacious against $\mathrm{A} /$ Hong 
Kong/156/97 (H5N1) and A/Hong Kong/1074/99 (H9N2) influenza viruses. Antiviral Res 2000;48:101-15.

7. Yuen KY, Wong SS. Human infection by avian influenza A H5N1. Hong Kong Med J 2005;11:189-99.

8. Aoki FY. Amantadine and rimantadine. In: Nicholson KG, Webster RG, Hay AJ, eds. Textbook of Influenza. Oxford: Blackwell Science, 1998:457-76.

9. Hayden FG, Gubareva LV, Monto AS, et al; Zanamivir Family Study Group. Inhaled zanamivir for the prevention of influenza in families. N Engl J Med 2000;343:1282-9.

10. Cass LM, Gunawardena KA, Macmahon MM, Bye A Pulmonary function and airway responsiveness in mild to moderate asthmatics given repeated inhaled doses of zanamivir. Respir Med 2000;94:166-73

11. Welliver R, Monto AS, Carewicz O, et al; Oseltamivir Post Exposure Prophylaxis Investigator Group. Effectiveness of oseltamivir in preventing influenza in household contacts: A randomized controlled trial. JAMA 2001;285:748-54.

12. Hayden FG, Belshe RB, Clover RD, Hay AJ, Oakes MG, Soo W. Emergence and apparent transmission of rimantadine-resistant influenza A virus in families. N Engl J Med 1989;321:1696-702.

13. Galbraith AW, Oxford JS, Schild GC, Watson GI. Protective effect of 1-adamantanamine hydrochloride on influenza A2 infections in the family environment: A controlled double-blind study. Lancet 1969;2:1026-8.

14. Hayden FG, Belshe R, Villanueva C, et al. Management of influenza in households: A prospective, randomized comparison of oseltamivir treatment with or without postexposure prophylaxis. J Infect Dis 2004;189:440-9.

15. Peters PH Jr, Gravenstein S, Norwood P, et al. Long-term use of oseltamivir for the prophylaxis of influenza in a vaccinated frail older population. J Am Geriatr Soc 2001;49:1025-31.

16. Oker-Blom N, Hovi T, Leinikki P, et al. Protection of man from natural infection with influenza A2 Hong Kong virus by amantadine: A controlled field trial. Br Med J 1970;3:676-8.

17. Dolin R, Reichman RC, Madore HP, Maynard R, Linton PN, Webber-Jones J. A controlled trial of amantadine and rimantadine in the prophylaxis of influenza A infection. $N$ Engl J Med 1982;307:580-4.

18. Payler DK, Purdham PA. Influenza A prophylaxis with amantadine in a boarding school. Lancet 1984;1:502-4

19. Monto AS, Robinson DP, Herlocher ML, Hinson JM Jr, Elliott MJ, Crisp A. Zanamivir in the prevention of influenza among healthy adults: A randomized controlled trial. JAMA 1999;282:31-5.

20. Hayden FG, Atmar RL, Schilling M, et al. Use of the selective oral neuraminidase inhibitor oseltamivir to prevent influenza. N Engl J Med 1999;341:1336-43.

21. Mast EE, Harmon MW, Gravenstein S, et al. Emergence and possible transmission of amantadine-resistant viruses during nursing home outbreaks of influenza A (H3N2).

Am J Epidemiol 1991;134:988-97.

22. Harper SA, Fukuda K, Uyeki TM, Cox NJ, Bridges CB; Centers for Disease Control and Prevention (CDC) Advisory Committee on Immunization Practices (ACIP). Prevention and control of influenza: Recommendations of the Advisory Committee on Immunization Practices (ACIP). MMWR Recomm Rep 2004:53:1-40.

23. Uhnoo I, Linde A, Pauksens K, Lindberg A, Eriksson M, Norrby R; Swedish Consensus Group. Treatment and prevention of influenza: Swedish recommendations. Scand J Infect Dis 2003;35:3-11.

24. Bright RA, Medina MJ, Xu X, et al. Incidence of adamantane resistance among influenza A (H3N2) viruses isolated worldwide from 1994 to 2005: A cause for concern. Lancet 2005;366:1175-81.

25. Centers for Disease Control and Prevention. CDC Recommends against the Use of Amantadine and Rimantadine for the Treatment or Prophylaxis of Influenza in the United States during the 2005-06 Influenza Season. <www.cdc.gov/flu/han011406.htm> (Version current at October 11, 2006).

26. Influenza: Report of the Committee on Infectious Diseases. In: Pickering L, ed. Red Book. Elk Grove Village: American College of Pediatrics 2003:382-91.

27. Belshe RB, Gruber WC. Prevention of otitis media in children with live attenuated influenza vaccine given intranasally. Pediatr Infect Dis J 2000;19(Suppl):S66-71.
28. Kiso M, Mitamura K, Sakai-Tagawa Y et al. Resistant influenza A viruses in children treated with oseltamivir: Descriptive study. Lancet 2004:364:759-65.

29. Ison MG, Gubareva LV, Atmar RL, Treanor J, Hayden FG. Recovery of drug-resistant influenza virus from immunocompromised patients: A case study. J Infect Dis 2006;193:760-4

30. Gubareva LV. Molecular mechanisms of influenza virus resistance to neuraminidase inhibitors. Virus Res 2004;103:199-203.

31. Yen H-L, Herlocher LM, Hoffmann E, et al. Neuraminidase inhibitor-resistant influenza viruses may differ substantially in fitness and transmissibility. Antimicrob Agents Chemother 2005;49:4075-84.

32. Hayden F, Klimov A, Tashiro M, et al. Neuraminidase inhibitor susceptibility network position statement: antiviral resistance in influenza A/H5N1 viruses. Antivir Ther 2005;10:873-7. (Erratum in 2006;11:130).

33. McCullers JA. Effect of antiviral treatment on the outcome of secondary bacterial pneumonia after influenza. J Infect Dis 2004;1:190:519-26.

34. Monto AS, Fleming DM, Henry D, et al. Efficacy and safety of the neuraminidase inhibitor zanamivirin the treatment of influenza A and B virus infections. J Infect Dis 1999;180:254-61.

35. Nicholson KG, Aoki FY, Osterhaus AD, et al. Efficacy and safety of oseltamivir in treatment of acute influenza: A randomised controlled trial. Neuraminidase Inhibitor Flu Treatment Investigator Group. Lancet 2000;355:1845-50. (Erratum in 2000;356:1856).

36. Boivin G, Hardy I, Tellier G, Maziade J. Predicting influenza infections during epidemics with use of a clinical case definition. Clin Infect Dis 2000;31:1166-9.

37. Govaert TM, Dinant GJ, Aretz K, Knottnerus JA. The predictive value of influenza symptomatology in elderly people. Fam Pract 1998; 15:16-22.

38. Peltola V, Reuanen T, Ziegler T, et al. Accuracy of clinical diagnosis of influenza in outpatient children. Clin Infect Dis 2005;41:1198-200

39. Peltola V, Ziegler T, Ruuskanen O. Influenza A and B virus infections in children. Clin Infect Dis 2003;36:299-305.

40. Whitley RJ, Hayden FG, Reisinger KS, et al. Oral oseltamivir treatment of influenza in children. Pediatr Infect Dis ] 2001;20:127-33. (Erratum in 2001;20:421).

41. Togo Y, Hornick RB, Felitti VJ, et al. Evaluation of therapeutic efficacy of amantadine in patients with naturally occurring A2 influenza. JAMA 1970;211:1149-56.

42. Wingfield WL, Pollack D, Grunert RR. Therapeutic efficacy of amantadine $\mathrm{HCl}$ and rimantadine $\mathrm{HCl}$ in naturally occurring influenza A2 respiratory illness in man. N Engl J Med 1969;281:579-84.

43. Hayden FG, Osterhaus AD, Treanor JJ, et al. Efficacy and safety of the neuraminidase inhibitor zanamivir in the treatment of influenza virus infections. GG167 Influenza Study Group. N Engl J Med 1997;337:874-80.

44. The MIST (Management of Influenza in the Southern Hemisphere Trialists) Study Group. Randomised trial of efficacy and safety of inhaled zanamivir in treatment of influenza A and $B$ virus infections. Lancet 1998;352:1877-81. (Errata in 1999;353:504 and 1999;353:1104).

45. Treanor JJ, Hayden FG, Vrooman PS, et al. Efficacy and safety of the oral neuraminidase inhibitor oseltamivir in treating acute influenza: A randomized controlled trial. US Oral Neuraminidase Study Group. JAMA 2000;283:1016-24.

46 Aoki FY, Macleod MD, Paggiaro P, et al. Early administration of oral oseltamivir increases the benefits of influenza treatment. J Antimicrob Chemother 2003;51:123-9.

47. Aoki FY, Sitar DS. Amantadine kinetics in healthy elderly men Implications for influenza prevention. Clin Pharmacol Ther 1985;37:137-44.

48. Murphy KR, Eivindson A, Pauksens K, et al. Efficacy and safety of inhaled zanamivir for the treatment of influenza with asthma or chronic obstructive pulmonary disease. Clin Drug Invest 2000;20:337-49.

49. Whitley RJ, Young, N, Ipe D, et al. Safety and acceptability of oseltamivir liquid formulation in the tratment of influenza in children aged one to 12 years. In: 9th International Congress of Chemotherapy, Buenos Aires, 2000. 
50. Oo C, Barrett J, Hill G, et al. Pharmacokinetics and dosage recommendations for an oseltamivir oral suspension for the treatment of influenza in children. Paediatr Drugs 2001;3:229-36.

51. Wooltorton E. Oseltamivir (Tamiflu) unsafe in infants under 1 year old. CMAJ 2004;170:336.

52. Okamoto S, Kamiya I, Kishida K, Shimakawa T, Fukui T, Morimoto T. Experience with oseltamivir for infants younger than 1 year old in Japan. Pediatr Infect Dis J 2005;24:575-6.

53. Tamura D, Miura T, Kikuchi Y. Oseltamivir phosphate in infants under 1 year of age with influenza infection. Pediatr Int 2005:47:484.

54. US Food and Drug Administration. Tamiflu Pediatric Adverse Events: Questions and Answers.

<www.fda.gov/cder/drug/infopage/tamiflu/QA20051117.htm> (Version current at September 27, 2006).

55. US Food and Drug Administration. One Year Post-Exclusivity Adverse Event Review for Tamiflu (oseltamivir). <www.fda.gov/ohrms/dockets/ac/05/slides/2005-4180s_03_truffa.ppt> (Version current at September 27, 2006).

56. Centers for Disease Control and Prevention. Antiviral agents for influenza: Dosage.

$<$ www.cdc.gov/flu/professionals/treatment/ dosage.htm> (Version current at October 11, 2006).

57. Makela MJ, Pauksens K, Rostila T, et al. Clinical efficacy and safety of the orally inhaled neuraminidase inhibitor zanamivir in the treatment of influenza: A randomized, double-blind, placebo-controlled European study. J Infect 2000;40:42-8.

58. Hedrick JA, Barzilai A, Behre U, et al. Zanamivir for treatment of symptomatic influenza $\mathrm{A}$ and $\mathrm{B}$ infection in children five to twelve years of age: A randomized controlled trial. Pediatr Infect Dis J 2000;19:410-7.

59. Canadian Task Force on Preventive Health Care. New grades for recommendations from the Canadian Task Force on Preventive Health Care. CMAJ 2003;169:207-8.

\section{INFECTIOUS DISEASES AND IMMUNIZATION COMMITTEE}

Members: Drs Simon Richard Dobson, BC Children's Hospital, Vancouver, British Columbia; Joanne Embree, University of Manitoba, Winnipeg, Manitoba (chair); Joanne Langley, IWK Health Centre, Halifax, Nova Scotia; Dorothy Moore, The Montreal Children's Hospital, Montreal, Quebec; Gary Pekeles, The Montreal Children's Hospital, Montreal, Quebec (board representative); Élisabeth Rousseau-Harsany, Hôpital SainteJustine, Montreal, Quebec (board representative); Lindy Samson, Children's Hospital of Eastern Ontario, Ottawa, Ontario

Consultant: Dr Noni MacDonald, Department of Pediatrics, IWK Health Centre, Halifax, Nova Scotia

Liaisons: Drs Upton Allen, The Hospital for Sick Children, Toronto, Ontario (Canadian Pediatric AIDS Research Group); Scott Halperin, IWK Health Centre, Halifax, Nova Scotia (IMPACT); Monica Naus, BC Centre for Disease Control, Vancouver, British Columbia (Health Canada, National Advisory Committee on Immunization); Larry Pickering, Centers for Disease Control and Prevention, Atlanta, Georgia, USA (American Academy of Pediatrics, Committee on Infectious Diseases)

Principal authors: Drs Upton D Allen, University of Toronto, Toronto, Ontario; Fred Y Aoki, University of Manitoba, Winnipeg, Manitoba; H Grant Stiver, University of British Columbia, Vancouver, British Columbia

ASSOCIATION OF MEDICAL MICROBIOLOGY AND INFECTIOUS DISEASE CANADA GUIDELINES COMMITTEE Drs Gerald Evans (Chair), David Haldane, Elizabeth Lee Ford-Jones, Michel Laverdiere, Lindsay Nicolle, Corinna Quan, Kathryn Suh 


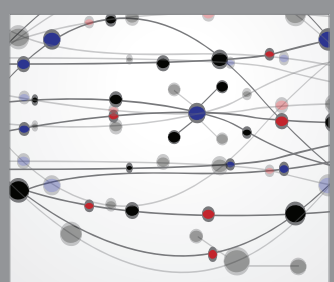

The Scientific World Journal
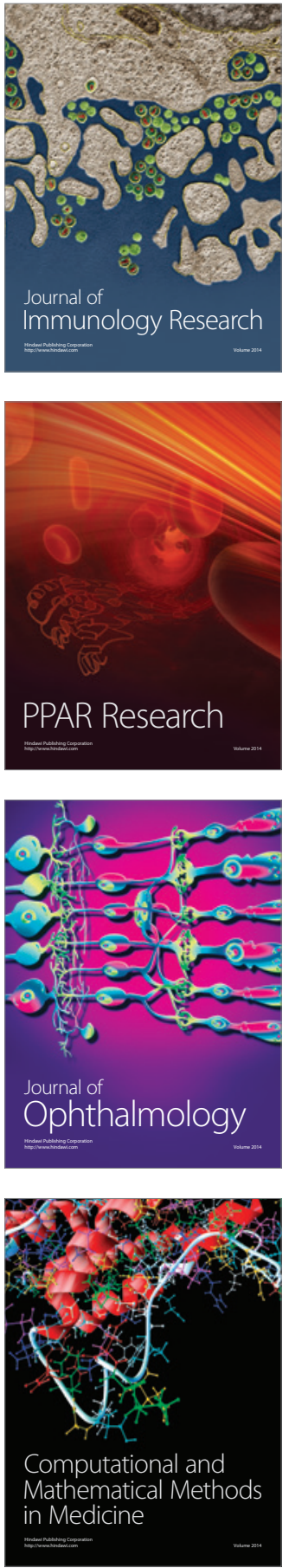

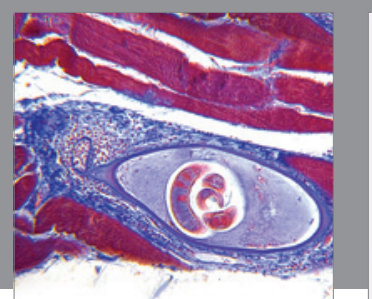

Gastroenterology Research and Practice

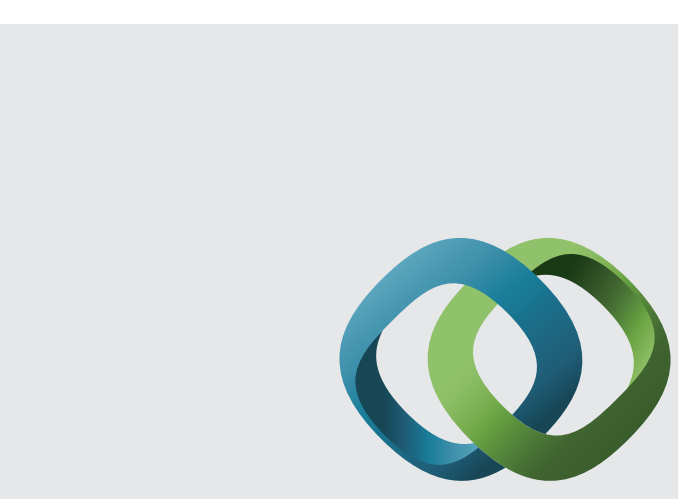

\section{Hindawi}

Submit your manuscripts at

http://www.hindawi.com
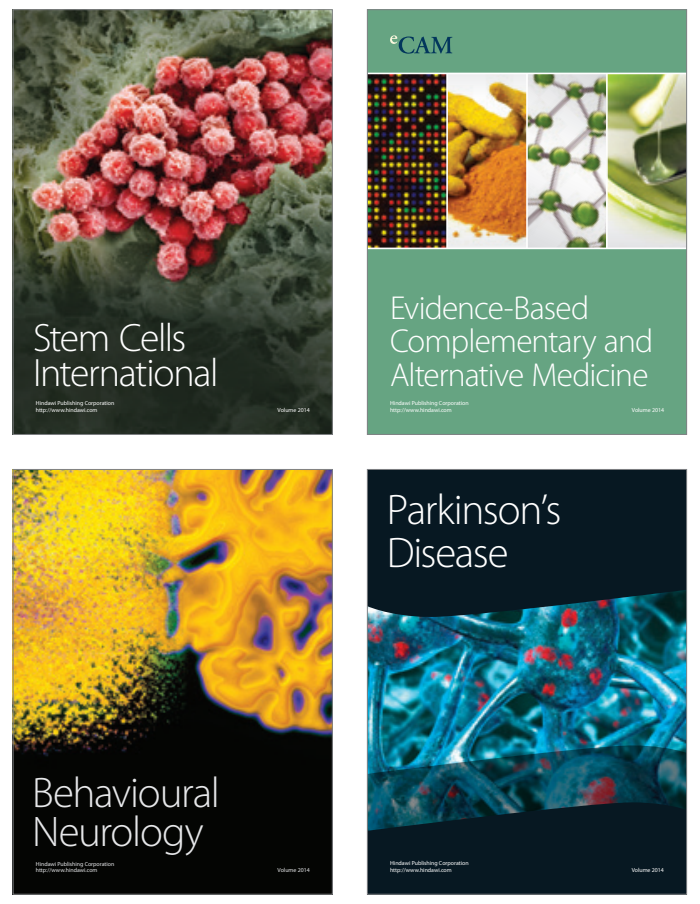
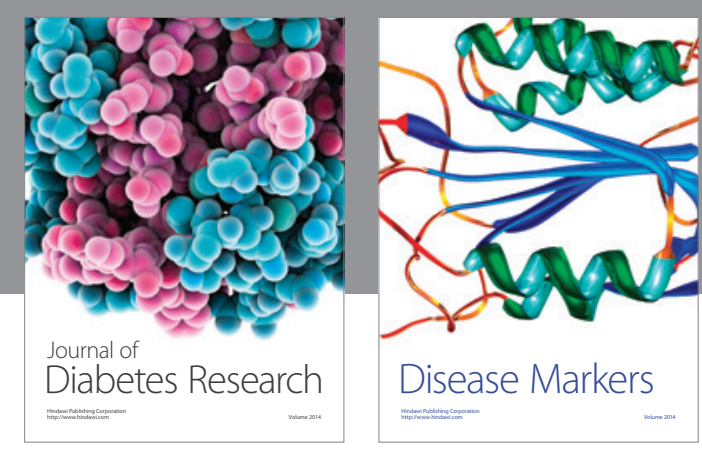

Disease Markers
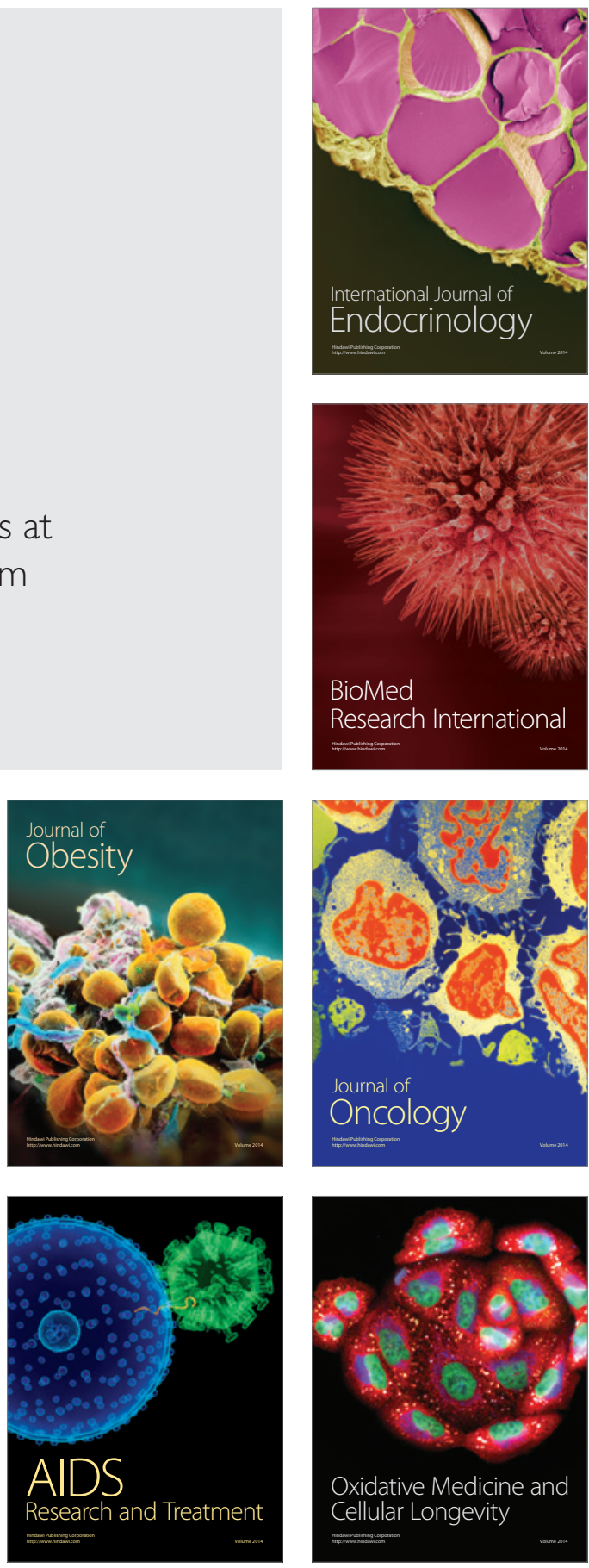